'Liika työnteko tappaa japanilaisia. Ylitöitä tehdään rajattomasti ja kesken loman tullaan töihin.

Teizo Miyazaki tunnettiin kovaksi työntekijäksi Sai Nippon Printing -kirjapainossa. Hän teki koneensa vieressä 24 tunnin mittaisia vuoroja joka toinen vuorokausi vuodesta 1968 aina vuoteen 1975 , jolloin hän sïrtyi eläkkeelle. Se ei kuitenkaan merkinnyt Miyazakin töiden loppumista yhtiössä korkeasta verenpaineesta huolimatta hän jatkoi 24 tunnin vuorojen tekemistä... Teizo Miyazaki kuoli 1977 aivoverenvuotoon... Miyazakin kuolema kirjattiin määritteellä 'karoshi', erityissanalla, joka yhä useammin on alkanut tunkeutua japanilaisten tietoisuuteen. Karoshi tarkoittaa liiasta työnteosta johtuvaa kuolemaa. Tapauksia on vuosittain yli 10000 , arvioi suurlehti Yomiuri... Yksistään suurin sallittu viikkotuntimäärä on huhtikuusta lähtien ollut 44 , ja 40 tunnin työviikko on vielä kaukana. Tämä ei kuitenkaan kerro koko totuutta, läheskään. Ylityöt kuuluvat olennaisena - ja jopa velvollisuudenomaisina - piirteenä työntekijän elämään... Monet tulevat yhä kesken loman töihin. Lomat ovat lyhyet, mutta sosiaalinen paine saa monet jättämään pitämättä vähäisetkin lomapäivät..."

Juhani Lompolo, HELSINGIN SANOMAT (1991)

\title{
Japanilaiset oikeassa
}

\section{- TYÖ EDELLEENKIN PARAS OPETTAJA}

Aikuiskasvatuksen 2/1991 artikkelissa Kenneth Abrahamsson vertaa Japanin ja Ruotsin aikuiskoulutusjärjestelmää sekä korostaa erityisesti työssä oppimisen merkitystä. Hän ennustaa myös henkilöstökoulutuksen merkityksen lisääntymistä kuluvalla vuosikymmenellä sekä pohtii, miten suuri osa työajasta voidaan käyttää uuden oppimiseen.

En voi kerskua itse olevani mikään Japani-asiantuntija, mutta kerran siellä käyneenä ja heidän koulutuksensa kehittymistä seuranneena muutama kommentti Abrahamssonin artikkeliin:

Säännöllinen vuotuinen työaika Japanissa oli viime vuonna 2143 tuntia. Suomessa työskenneltiin keskimäärin 1716 tuntia eli 427 tuntia vähemmän. Japanilaiset saavat siis opiskella kaksi kuukautta päätoimisesti vuodessa ja vielä tekevät enemmän työtä kuin suomalaiset.

Japanilaiset työnantajat rekrytoivat ja kouluttavat henkilöstöään nykyisten ja tulevaisuuden tarpeiden mukaisesti. Jokainen suurempi yritys on kehittänyt oman koulutusstrategian, suunnitelmat ja koulutusohjelmat. Tavoitteena on luoda, pitää yllä ja kohottaa ammattitaidon tasoa, mutta tavoitteet ja prioriteetti saattavat erota yrityksestä toiseen. Pääpaino on johdon ja esimieskunnan koulutuksessa.

Tärkeimpiä koulutusmuotoja ovat järjestelmällinen työnopastus ja työnkierto, sisäiset ja ulkoiset kurssit sekä laatupiiritoiminta. Itseopiske- 
lu ja ohjattu lukeminen kuuluvat niin ikään keskeisinä koulutusmuotoina systeemiin. Ulkoista koulutusta käytetään pääasiassa kielten opettamiseen ja liikkeenjohdon kouluttamiseen.

Suurimmilla yrityksillä on myös omia oppilaitoksiaan henkilöstön kouluttamista varten. Opetussuunnitelma sisältää käytännön työn opetusta sekä tietopuolista opetusta.

Monet yritysten oppilaitoksista ovat sisäoppilaitoksia. Kuri on kova ja opetus tehokasta. Päivä alkaa aamuvoimistella, lipunnostolla ja yrityksen "taistelulaululla". Kaikilla on yhdenmukaiset koulupuvut, mikä edistääjapanilaisille tärkeää ryhmäsidonnaisuutta.

Omissa oppilaitoksissa koulutetaan henkilöstön eliitti. Nämä henkilöt ovat samalla yritysten avaintyövoima. Työnantaja rohkaisee heitä kehittämään itseään ja pysymään pitkään yrityksessä.

Henkilökuntaa täydennetään kerran vuodessa. Tämä tapahtuu silloin, kun koulut päättyvät. Samaan aikaan yritykseen rekrytoitu ikäluokka muodostaa ikäkohortin, jonka status määräytyy yleissivistävän ja ammatillisen peruskoulutuksen sekä palveluajan mukaan. Vuosien saatossa palkka paranee ja status nousee. Enemmistö tällä tavoin rekrytoiduista nuorista on käynyt yleissivistävän tai ammatillisen lukion.
Merkille pantavaa muuten on myös, että ylioppilastutkinnon suorittaneet insinöörit tai johtajat aloittavat yrityksessä työnsä manuaalisissa tai toimistotehtävissä. Yrityksen sisäisen koulutuksen ja kurssien avulla heidät koulutetaan työnantajan sopivaksi katsomaan tehtävään. Päinvastoin kuin meillä, nuoret rekrytoidaan yritykseen eikä johonkin tarkasti määriteltyyn ammattiin.

Japanilaisten työnantajien rekrytointipolitiikassa on suuria eroja. Suuret yritykset arvostavat enemmän koulutustaustoja, älykkyyttä ja kykyä kuin työssä hankittua kokemusta. Pienet yritykset priorisoivat puolestaan niitä, joilla on koulutus ja ammattitaito siihen tehtävään, joka yrityksissä on tarjolla.

Ehkä nämä kommentit selittävät, miksi työssä oppiminen ja omaehtoinen koulutus Japanissa ovat tärkeitä. Abrahamssonin artikkeli on mielenkiintoinen, mutta tapa vertailla puutteellinen. Siitä huolimatta työ on edelleen monissa tapauksissa paras kouluttaja. Tärkeä tekijä on opettava työorganisaatio, jollaisia meillä Suomessakin on runsaasti. Työssä saatua oppia ei vielä vain arvosteta riittävästi, ennen kuin näyttötutkinnot ja aikuisten tutkintojärjestelmä on toteutettu.

\section{KARI PURHONEN}

